\title{
Molecular characterization of group A rotavirus (RVA) strains detected in bovine and porcine species: Circulation of unusual rotavirus strains. A study from western, India
}

\author{
V. S. TATTE ${ }^{1}$, M. JADHAV², V. C. INGLE ${ }^{2}$, V. GOPALKRISHNA ${ }^{1^{*}}$ \\ ${ }^{1}$ Enteric Viruses Group, National Institute of Virology Pune and ${ }^{2}$ Department of Veterinary Microbiology and Animal Biotechnology \\ Nagpur, India \\ Received February 26, 2018; revised April 25, 2018; accepted February 4, 2019

\begin{abstract}
Summary. - Group A rotaviruses (RVA) are considered as important causative agents of diarrhea in both human and animal species. Fecal specimens $(\mathrm{n}=300)$ were collected from both diarrheic and healthy animals during the year 2009 from animal farms from Nagpur (Maharashtra), Western India. RVA antigen was detected by ELISA in 3.1-25\% and 72\% in bovine and porcine species, respectively. Genotyping based on VP6, VP7 and VP4 of RVA-positive samples showed predominance of genotype I-1 (63\%) and genotype I-2 (37\%), G4 (45.5\%) and G10 (27.3\%) genotypes, P[6] (72.7\%) and P[8] (18.1\%) genotypes, respectively. Other RV genotypes such as G1(4.5\%), G2(9.1\%), G3(4.5\%) and mixed infections (9.1\%) were detected at low level. Predominance of unusual G-P combinations (9/23, 39.1\%) were observed. Circulation of G2P[8] and mixed infections with G1, $\mathrm{G} 3, \mathrm{P}[6]$ and $\mathrm{G} 1, \mathrm{P}[8], \mathrm{P}[6])$ are reported in porcine species for the first time in Western India. In conclusion the present study highlights the circulation of unusual G-P combinations and VP6 genogroup specificities of human RVA strains indicative of possible interspecies transmission and reassortment events in animal species. The study further warrants utmost need for such surveillance studies across the country to understand the role of animals as genetic reservoirs for the emergence of RVA strains pathogenic for humans.
\end{abstract}

Keywords: rotaviruses; genotypes; unusual G-P types; animals

\section{Introduction}

Group A rotaviruses (RVA) play a major role as a cause of severe diarrhea in children worldwide, and they are estimated to cause more than 453,000 deaths each year among children below 5 years of age (Estes and Kapikian, 2007; Tate et al., 2012). It is also considered as one of the most frequently detected enteropathogen associated with acute gastroenteritis in young animals in farms (Papp et al., 2013).

Rotaviruses (RVs) are the members of the genus Rotavirus (the family Reoviridae), they contain 11 segments of double-stranded RNA encased in a triple-layered capsid.

"Corresponding author. E-mail: gopalvk58@hotmail.com; phone: +91-20-26127301/26127303.

Abbreviations: $\mathrm{RV}(\mathrm{s})=$ rotavirus(es); $\mathrm{RVA}=$ group A rotavirus(es); $\mathrm{VP}=$ virus protein
These segments encode six structural (VP1 to VP4, VP6, VP7) and six nonstructural (NSP1-NSP6) proteins (Estes and Kapikian, 2007). The two outer capsid proteins VP7 and VP4 define $G$ and $P$ serotypes, respectively, and independently induce neutralizing antibodies signifying their role in protective immunity (Estes and Kapikian, 2007). Based on the new rotavirus classification system, the percent nucleotide sequence identity for each of the 11 segments has been defined to classify each segment into different genotypes (Matthijnssens et al., 2008; Matthijnssens et al., 2011). According to this classification system, $35 \mathrm{G}$ and $50 \mathrm{P}$ genotypes of RVAs have been described in human and animal infections (Matthijnssens et al., 2011) [https://rega.kuleuven.be/cev/ viralmetagenomics/virus-classification/rcwg].

Till date, there have been twelve RVA G genotypes (G1 to G6, G8 to G12, and G26) and thirteen RVA P genotypes ( $\mathrm{P}[1], \mathrm{P}[5]$ to $\mathrm{P}[8], \mathrm{P}[11], \mathrm{P}[13], \mathrm{P}[19], \mathrm{P}[23], \mathrm{P}[26$ ], $\mathrm{P}[27]$, $\mathrm{P}[32]$, and $\mathrm{P}[34]$ ) detected in pigs (Maneekarn et al., 2006; 
Martella et al., 2007; Parra et al., 2008; Collins et al., 2010; Matthijnssens et al., 2011). Among these the most common RVA genotypes identified in porcine species are G3, G4, G5, G11, P [5], P[6] and P[28]. Similarly, among bovine species infections with G6, G8, and G10, P[1], P[5], and P[11] genotypes have been found predominant along with sporadic infections of G1, G3, G5, G15, P[14], P[15], P[17], and P[21] genotypes (Estes and Kapikian, 2007; Cashman et al., 2010; Matthijnssens et al., 2010). In humans, five RV G genotypes (G1 to G4, and G9) and three P genotypes (P[4], P[6], and $\mathrm{P}[8]$ ) represent majority of the clinically important RVA strains (Santos and Hoshino, 2005). The RVA surveillance studies carried out after the introduction of the RVA vaccine into human populations has resulted in the increase in the unusual RV strains, including those commonly detected in porcine (pigs) and bovine (cattle) animal species, novel genotypes, animal-like strains, or animal-human rotavirus reassortants (Gentsh et al., 2005; Steyer et al., 2008; Iturriza et al., 2011; Malik et al., 2012; Miyazaki et al., 2012; Theuns et al., 2016). Animal RVAs are, therefore, regarded as a potential reservoir for the genetic diversity in human RVA, and consequently their ecology has been of great concern (Martella et al., 2010).

Over a period of time, there has been a difference in the circulation pattern of G and P RVA genotypes observed in bovine and porcine species of animals. In India, circulation of mainly G6 (25-35\%), G10 (50-60\%) and G3 (10.2\%) genotypes of bovine RV and G6 and G12 genotypes of porcine RVs have been reported (Ghosh et al., 2007; Manuja et al., 2008; Sharma et al., 2009; Ghosh et al., 2015). These findings suggest that interspecies transmission of rotaviruses between humans and animals or animals to animals might take place in nature (Nagai et al., 2015; Theuns et al., 2015; Chakraborty et al., 2016). Accordingly, animal RVAs have been considered to be of great concern for zoonotic potential and resulting in economic losses in commercial cattle farms and piggeries.

Although, there are few reports available from India on animal rotaviruses (Varshney et al., 2002; Chitambar et al., 2011; Dubal et al., 2013; Mondal et al., 2013), so far no comparative surveillance studies are reported on rotavirus infection and their genotype distribution to indicate possible evidence showing interspecies transmission, i.e human to animal transmission of bovine and porcine species available from a single animal farm located in western India. Keeping in mind the present scenario and importance of the problem, the present study was undertaken to understand the epidemiology, circulation pattern and genotype distribution of rotaviruses (RVA) among bovine and porcine species analyzed from the animal farms located in Nagpur, (Maharashtra), Western India. Furthermore, the information gained from the present study would be helpful for elucidating the possible evidence of interspecies transmission and genetic reassortment between rotaviruses of bovine, porcine and human origin, which can fill up some of the gaps pertaining to rotavirus disease, which is a global public health problem.

\section{Material and Methods}

Specimens. Fecal samples $(\mathrm{n}=300)$ collected from either male or female cattle calves $(n=100)$, buffalo calves $(n=100)$ and piglets ( $\mathrm{n}=100)$ aged $<1$ year, and maintained in different animal farms in and around Nagpur, central India during the year 2009, were included in the study. Stool samples were collected per rectally from both diarrheic and non-diarrheic animals in sterile screw capped plastic vials. These samples were collected with the written consent taken from the animal handlers. Ten percent (w/v) fecal sample suspension was prepared in $0.01 \mathrm{M}$ phosphate buffered saline (PBS), pH 7.2 containing $0.01 \mathrm{M} \mathrm{CaCl}_{2}$ Supernatants obtained after centrifugation at $805 \mathrm{~g}$ for 15 minutes were stored at $-70^{\circ} \mathrm{C}$ until use for detection of rotavirus antigen and genotypes.

Detection of group A rotavirus antigen. All samples were tested for the presence of rotavirus antigen using commercially available rotavirus antigen detection kit (Generic Assay, Berlin, Germany) as per manufacturer's protocol. The cut-off value was calculated as $0.2+$ Negative Control (NC) and all the samples above the cut-off were considered as positive.

RNA extraction. Nucleic acid (RNA) was extracted from $10 \%$ $(\mathrm{w} / \mathrm{v})$ fecal suspensions using TRIZOL LS reagent (Invitrogen, Carlsbad, CA) according to the manufacturer's instructions. The total RNA recovered was suspended in $10 \mu \mathrm{l}$ of RNase free water and stored at $-70^{\circ} \mathrm{C}$ until use.

RT-PCR and genotyping of RVA's. The reverse transcription PCR (RT-PCR) was performed on all RVA ELISA-positive samples using Qiagen One Step RT-PCR kit (Hilden, Germany). Primers used in the study were selected from the subgrouping region of the VP6 gene (379 bp) as described earlier (Iturriza-Gomara et al., 2003). The VP7 and VP4 genes of RVA were genotyped by multiplex reverse transcription (RT) PCR according to the methods described earlier with minor modifications (Chitambar et al., 2008). All the PCR products, including first-round and multiplex PCRs, were electrophorized on $2 \%$ agarose gels using $1 \mathrm{x}$ Tris Acetate EDTA (TAE) buffer $\mathrm{pH} 8.3$, containing ethidium bromide $(0.5 \mu \mathrm{g} / \mathrm{ml})$ and visualized under gel documentation system (AlfaImager HP Imaging System, San Jose, California, USA).

Nucleotide sequencing and phylogenetic analysis. The first round PCR products obtained for RVA VP6 gene (379 bp) and multiplex RT-PCR products for RVA VP7 gene (618 bp, 521 bp, 682 bp, 452 bp, $266 \mathrm{bp}$ ) and RVA VP4 gene ( $345 \mathrm{bp}, 267 \mathrm{bp}$ ) were purified on minicolumns (QIAquick, Qiagen, Valencia, CA). Cycle sequencing was carried out using ABI-PRISM Big Dye Terminator Cycle Sequencing kit (Applied Biosystems, Foster city, CA) and ABI-PRISM 310 Genetic Analyzer (Applied Biosystems, Foster city, CA). The sequences of the genes encoding VP6, VP7 and VP4 were aligned with the corresponding sequences of the rotavirus strains avail- 
able in GenBank by using Clustal W (Thompson et al., 1994). The phylogenetic analysis was carried out in MEGA 5 by using Kimura -2 parameter and Neighbour Joining (NJ) algorithm (Tamura et al., 2011). The reliability of different phylogenetic groupings was confirmed by using the bootstrap test (1000 bootstrap replications).

\section{Results}

\section{Rotavirus antigen detection}

Rotavirus antigen was detected in $10.6 \%(32 / 300)$ of the fecal specimens collected from different species of animals (8/100, buffaloes; $1 / 100$, calves and 23/100, piglets) by ELISA. Among all the rotavirus-positive samples analyzed, RV positivity was found higher $(71.8 \%, 23 / 32)$ among piglets than in buffalo calves $(25 \%, 8 / 32)$ and cow calves $(3.1 \%, 1 / 32)$. Of the 9 specimens collected from bovine, 5/9 specimens were from non-diarrheic and 4/9 from diarrheic animals. Similarly, 22/23 specimens from porcine were non-diarrheic and only one was from diarrheic animal.

\section{Rotavirus VP6 genotyping}

A total of 29/32 (90.6\%) rotavirus strains were detected by RT-PCR targeting the genogrouping region of the RV VP6 gene, which included 1/29 (3.4\%) in cow calves, 6/29 (20.7\%) in buffalo calves and 22/29 (75.9\%) in porcine species.

Of the 29 RVA strains analyzed in the study, 27 were typed for VP6 gene and sequencing analysis showed the predominance of I-1 (17/27, 63\%) followed by I-2 (10/27, $37.0 \%$ ) (Fig. 3), and two strains remained non-typeable. VP6 gene sequence analysis indicated VP6 genotype 2 (I-2) in $10 \%(1 / 10)$ of the strains in cow, $50 \%(5 / 10)$ strains in buffalo calf and $40 \%(4 / 10)$ of the strains in porcine species. However, VP6 genotype 1 (I-1) specificity was detected in $100 \%(17 / 17)$ of the strains in porcine species.

\section{Rotavirus VP7 and VP4 genotyping}

VP7 and VP4 genotyping was carried out for all 32 rotavirus-positive samples obtained from the animals. Based on VP7 and VP4 genotyping, a total of $28.1 \%$ (9/32) of the RVA-positive specimens were typed for both $\mathrm{G}$ and $\mathrm{P}$ types. Remaining specimens showed predominance of $G$ type (40.6\%, 13/32), 25\% (8/32) non-typeable and 6.3\% (2/32) P-typed (Table 1).

\section{RVA G-typing}

Among all the RVA strains typed for VP7 or for both VP7 and VP4 genes, i.e. $68.7 \%$ (22/32), predominance of G4 $(45.5 \%, 10 / 22)$ and G10 $(27.3 \%, 6 / 22)$ RVA genotypes were
Table 1. Distribution of VP7(G)-VP4(P) types detected in rotaviruspositive specimens from different animal species

\begin{tabular}{lcccc}
\hline G-P types & $\begin{array}{c}\text { Cow } \\
(\mathbf{n}=\mathbf{1})\end{array}$ & $\begin{array}{c}\text { Buffalo } \\
(\mathbf{n}=\mathbf{8})\end{array}$ & $\begin{array}{c}\text { Porcine } \\
(\mathbf{n}=\mathbf{2 3})\end{array}$ & $\begin{array}{c}\text { Total } \\
(\mathbf{n}=\mathbf{3 2})\end{array}$ \\
\hline Typed for both G and P & $(\mathbf{n}=\mathbf{0})$ & $(\mathbf{n}=\mathbf{0})$ & $(\mathbf{n}=\mathbf{9})$ & 9 \\
G4P[6] & 0 & 0 & 6 & \\
G2P[8] & 0 & 0 & 1 & \\
G1,G3P[6] & 0 & 0 & 1 & \\
G1P[8],P[6] & 0 & 0 & 1 & \\
\hline Typed only for G & $(\mathbf{n}=\mathbf{1})$ & $(\mathbf{n}=\mathbf{4})$ & $(\mathbf{n}=\mathbf{8})$ & 13 \\
G10 & 1 & 4 & 1 & \\
G4 & 0 & 0 & 4 & \\
G3 & 0 & 0 & 1 & \\
G2 & 0 & 0 & 1 & \\
G4,G10 & 0 & 0 & 1 & \\
\hline Typed only for P & $(\mathbf{n}=\mathbf{0})$ & $(\mathbf{n}=\mathbf{0})$ & $(\mathbf{n}=\mathbf{2})$ & 2 \\
P[8] & 0 & 0 & 1 & \\
P[6] & 0 & 0 & 1 & \\
Non-typed for both G-P & 0 & 4 & 4 & 8 \\
\hline
\end{tabular}

observed in porcine and bovine species. In the porcine species, presence of other RV genotypes such as G1(4.5\%; 1/22), G2(9.1\%, 2/22), G3(4.5\%; 1/22), and mixed infections in $9.1 \%(2 / 22)$ of the strains each with different [G1G3 $(n=1)$ and G4G10 $(\mathrm{n}=1)$ ] genotype combinations was noted. Nontypeable RV G types were also detected in $31.2 \%$ (10/32) of the strains from bovine $(n=6)$ and porcine $(n=4)$ species.

Most of the RV G4 strains (6 of 11) were found in combination with $\mathrm{P}[6]$, while five strains showed $\mathrm{P}$ non-typeability. All the seven G10 strains were found P non-typeable. One each of the G2 strain was found in combination with $P[8]$ and P non-typeability, respectively. RVA G1 and G3 genotype strains were found in combination with mixed $P$ genotypes $(\mathrm{P}[6]$ and $\mathrm{P}[8])$ and / or $\mathrm{P}[6]$ and/ or were $\mathrm{P}$ non-typeable.

\section{RVA P-typing}

Of those RV strains typeable for VP4 or both VP7 and VP4 genes, i.e $34.3 \%$ (11/32), predominance of $\mathrm{P}[6]$ (72.7\%, $8 / 11)$ followed by $\mathrm{P}[8](18.1 \%, 2 / 11)$ and mixed infections with $\mathrm{P}[6], \mathrm{P}[8]$ was found in $9.0 \%(1 / 11)$ of the porcine species only. Non-typeable P types were detected in $65.6 \%$ $(21 / 32)$ of the RVA strains analyzed among bovine $(n=9)$ and porcine $(\mathrm{n}=12)$ species.

\section{Combinations of G-P types}

Of the nine rotavirus strains typed for both the genes (VP7, VP4) in the porcine species, a total of four different G-P combinations were detected. Predominance of unusual RVA strains $(7 / 9,77.8 \%)$ was detected, which consisted of G2P [8] $(1 / 9,11.1 \%)$ and G4P[4] $(6 / 9,66.7 \%)$. Mixed infections $(22.2 \%, 2 / 9)$ of rotavirus strains with dual $G(G 1$, 


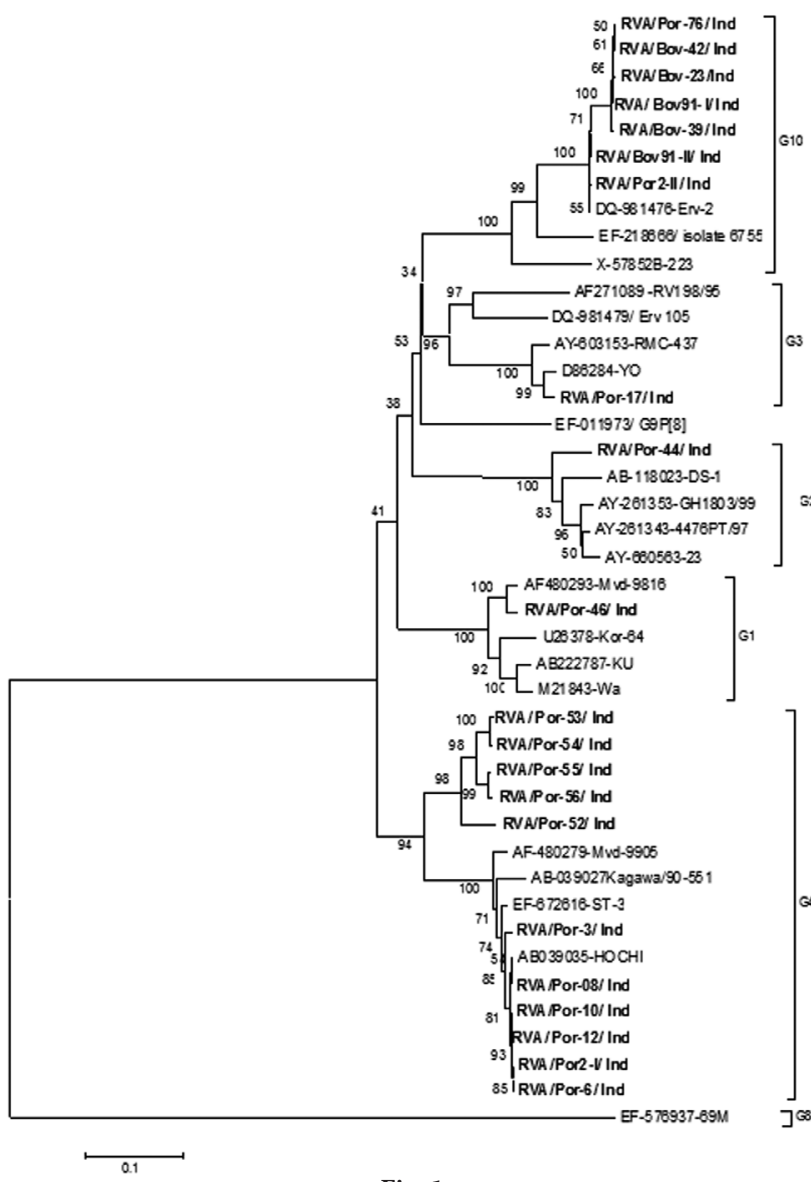

Fig. 1

Phylogenetic analysis of the partial nucleotide sequences of the VP7 gene for G1 (nt 344-904), G2 (nt 448-903), G3 (nt 280-900), G10 (nt 675-900) and G4 (nt 514-899) strains detected in bovine and porcine species

Strains of the present study have been highlighted in bold.

G3,P[6]) and $P(G 1, P[8], P[6])$ types were also detected. Interestingly, rotavirus strains with common genotype combinations (G-P types) were not observed in the study.

Sequencing and phylogenetic analysis of VP4-, VP6- and VP7-encoding genes

Nucleotide sequence analysis of VP4- $(\mathrm{n}=12)$, VP6$(\mathrm{n}=27)$ and VP7- $(\mathrm{n}=21)$ encoding genes of the rotavirus strains detected in single and/or mixed infections showed close identity with human rotavirus strains (Figs 1, 2 and 3). Detailed phylogenetic analysis of all strains in the study is shown in Table 2.

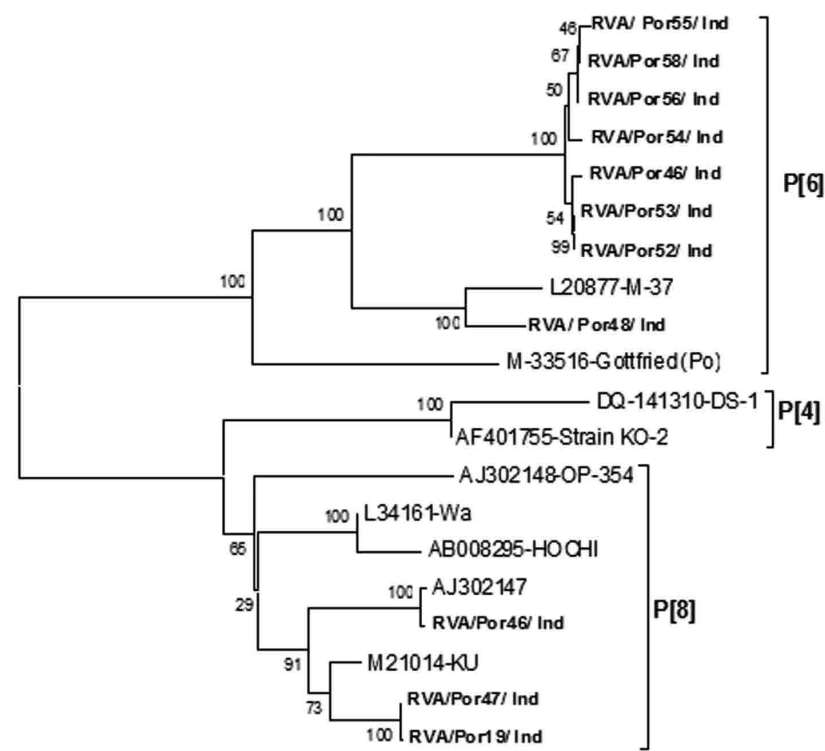

Fig. 2

Phylogenetic analysis of the partial nucleotide sequences of the VP4 gene for P[8] (nt 41-310) and for P[6] (nt 41-250) detected in porcine species

Strains of the present study have been highlighted in bold.

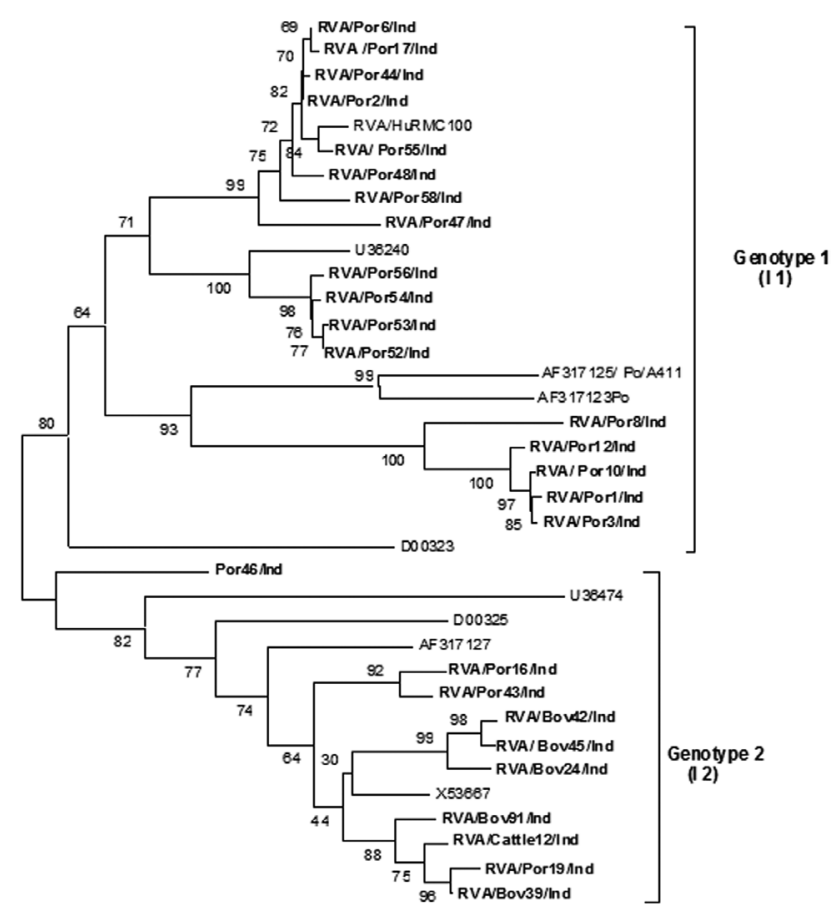

$\longdiv { 0 . 0 2 }$

Fig. 3

Phylogenetic analysis of the partial nucleotide sequences of VP6 gene (747-1126 nt) detected in bovine and porcine species Strains of the present study have been highlighted in bold. 
Table 2. Phylogenetic analysis of the VP4(P), VP6(I) and VP7(G) genotypes of rotavirus strains detected in fecal specimens from different animal species

\begin{tabular}{|c|c|c|c|c|}
\hline \multirow{2}{*}{$\begin{array}{l}\text { VP7(G) type } \\
(n=22)\end{array}$} & \multicolumn{2}{|c|}{ With reference strains } & \multicolumn{2}{|c|}{ Within the strains } \\
\hline & nt $\%$ & aa $\%$ & nt \% & aa\% \\
\hline G1 $(n=2)$ & $92.1-97.4$ & $88.7-96.1$ & 100 & 100 \\
\hline $\mathrm{G} 2(\mathrm{n}=2)$ & $90.9-63.5$ & $81.8-87.1$ & 100 & 100 \\
\hline G3 $(n=2)$ & $79.2-97.4$ & $74.2-95.7$ & 100 & 100 \\
\hline $\mathrm{G} 4(\mathrm{n}=11)$ & $84.2-99.7$ & $75.3-100$ & $85.4-100$ & $79.0-100$ \\
\hline $\mathrm{G} 10(\mathrm{n}=7)$ & $83.7-99.7$ & $83.7-99.7$ & $97.1-99.7$ & $97.1-99.7$ \\
\hline \multirow{2}{*}{$\begin{array}{l}\text { VP4(P) type } \\
(n=12)\end{array}$} & \multicolumn{2}{|c|}{ With reference strains } & \multicolumn{2}{|c|}{ Within the strains } \\
\hline & nt $\%$ & aa $\%$ & nt \% & aa $\%$ \\
\hline$P[6](n=9)$ & $80.7-95.0$ & $86.0-96.5$ & $86.0-100$ & $90.3-100$ \\
\hline$P[8](n=3)$ & $86.1-99.5$ & $83.6-99.3$ & $93.8-99.9$ & $94.2-100$ \\
\hline \multirow{2}{*}{$\begin{array}{l}\text { VP6(I) type } \\
(\mathrm{n}=27)\end{array}$} & \multicolumn{2}{|c|}{ With reference strains } & \multicolumn{2}{|c|}{ Within the strains } \\
\hline & nt $\%$ & aa \% & nt $\%$ & aa \% \\
\hline $\mathrm{I}-1(\mathrm{n}=17)$ & $80.4-98.2$ & $83.2-98.2$ & $98.0-99.7$ & $99.0-100$ \\
\hline $\mathrm{I}-2(\mathrm{n}=10)$ & $90.0-95.0$ & $98.2-99.2$ & $92.0-99.7$ & $96.0-100$ \\
\hline
\end{tabular}

\section{Discussion}

It is well known that rotaviruses cause acute infantile diarrhea both in humans and in animal species (Theuns et al., 2015; Chakraborty et al., 2016). However, understanding the zoonotic potential of animal RVA has been of a great concern worldwide (Martella et al., 2010; Matthijnssens et al., 2010; Iturriza-Gomara et al., 2011). Understanding the viral etiology of the animal population, together with constant monitoring of the RVA diarrhea, the genotypic distribution and the diversity of the RVA strains under circulation over a period of time will certainly help in development of intervention strategies. In the present study, RVA was detected by ELISA method in both bovine and porcine species. Recently, studies carried out worldwide used methods such as RT-PCR to detect RVAs in fecal samples of animal origin (Miyazaki et al., 2012; Saikrung et al., 2013). However, in our study ELISA detection of RV's was confirmed by VP6-based RT-PCR, genotyping using the VP7- and VP4-based multiplex PCR followed by sequencing and phylogenetic analysis.

In this study, detection rate of rotaviruses remarkably differed in healthy $(5 / 9,55.5 \% / 22 / 23,95.65 \%)$ and diarrheic $(4 / 9,44.44 \% / 1 / 23,4.34 \%)$ animals of bovine and porcine species. Prevalence rate of RV's in bovine species has been reported to vary between 2 to $98 \%$ worldwide (Midgley et al., 2012). In general, low detection rates (2-16\%) of RV's were reported in asymptomatic animals and higher rates (12-98\%) in diarrheic animals (Dhama et al., 2009). Interestingly, in the present study, contradictory findings were noted, demonstrating that asymptomatic rotavirus infection might be relatively more frequent in porcine species than in bovine species. These observations were in good agreement with the earlier reports available from Europe showing 16.7-20\% of RVA infections in asymptomtic piglets (Midgley et al.,
2012). In the study, RV G10 was the most common 'G' type found in bovine species in combination with non-typeable ' $\mathrm{P}$ ' genotype. These results differed from the studies carried out worldwide, including India, that reported predominance of G6P[5] or G6P[11] in bovine species (Cashman et al., 2010; Midgley et al., 2012; Ghosh et al., 2015). However, in the present study, these findings were similar to the earlier reports available from India showing predominance of RV G10 in contrast to other G types (G6 or G8) among bovine species (Manuja et al., 2008; Sharma et al., 2009). The diversity of both $\mathrm{G}$ and $\mathrm{P}$ types, which included a variety of unusual RVA genotypes, was higher among porcine species $(19 / 23,82.6 \%)$ as compared to the bovine species $(4 / 8,50 \%)$ and confirmed the findings of others reported worldwide (Martella et al., 2010; Collins et al., 2010; Midgley et al., 2012; Miyazaki et al., 2012; Theuns et al., 2016). Genetic analysis of the RVA strains from porcine and bovine species identified a variety of genotypes, including five G types (G1, G2, G3, G4 and G10), three P types (P[8], P[6] and P[NT]) and four different G-P combinations (G2P[8], G4P[6], G1,G3,P[6] and $\mathrm{G} 1, \mathrm{P}[8], \mathrm{P}[6])$. Except for the circulation of G4P[6] RVAs in porcine species, these findings differed from recent studies carried out in Japan, Belgium and other European countries, Iran and India that reported different G-P types (Midgley et al., 2012; Miyazaki et al., 2012; Chakraborty et al., 2016; Pourasgari et al., 2016; Theuns et al., 2016; Kumar et al., 2018).

The reason for such a great diversity of rotavirus genotypes in porcine species as compared to the bovine species is still unknown. The possibility might be differences in breeding practices and facilities, life span, and the extent of national and international trading and transport of animals (Midgley et al; 2012). RV G- types such as G1, G2 and G4 that are commonly seen in humans were detected only in porcine 
species. Of the most common human $\mathrm{P}$ types, $\mathrm{P}[4]$ and $\mathrm{P}[8]$, $\mathrm{P}[8]$ strains were seen in pigs. However, another rare human RV P [6] was also detected in porcine species. Molecular analyses of the strains of the present study revealed a closer relationship between human and porcine rotavirus strains than between human and bovine species, and these findings were similar to those reported recently from Europe (Midgley et al; 2012). Circulation of G2P[8] and mixed infections with RVA strains $(\mathrm{G} 1, \mathrm{G} 3, \mathrm{P}[6]$ and $\mathrm{G} 1, \mathrm{P}[8], \mathrm{P}[6])$ in porcine species is reported for the first time in Western India.

The G-P combinations of RVs found in humans are rarely detected in animals, and vice versa, which confirms that rotaviruses are largely host-specific. Till date, interspecies transmission events have been rarely reported and there is no epidemiological evidence indicating that rotaviruses are transmitted from animals. Similar and identical molecular characteristics between a particular human strain and animal strains have served as the basis for the recognition of such events. There may be no clinical relevance to the incidental transmission of RVs from animals to humans, but these events provide an opportunity for reassortments leading to the generation of novel strains that may be pathogenic to humans. Hence, constant efforts at the interface of veterinary medicine and public health is required for better understanding of the impact and incidence of rotavirus zoonoses and exploration of animal reservoirs. Recently, asymptomatic RVA infections in pigs and cattle have caused concern, as RVAs excreted from subclinically infected animals can cause a diarrheal outbreak in the herd (Steyer et al., 2008; Abe et al., 2009; Collins et al., 2010). Further, such RVAs may also represent a source of zoonotic transmission (Steyer et al., 2008).

In conclusion, the present study indicated that asymptomatic infections occurred more frequently in porcine species than bovine among animals. The study also highlighted a variety of unusual genotype combinations of rotavirus strains circulating in the study region. Such genetically divergent RVA infections could provide clues for reassortment events among human and animal species and possible evidence of interspecies transmission. However, the limitation of the study was that the analysis of rotavirus distribution in human population was not carried out in the same region as that of the animal rotavirus study. Therefore, it cannot be concluded or emphasized that interspecies transmission has occurred at this point of time. Hence, more such surveillance studies from different geographical regions in India are required to establish the nature of rotavirus strains circulating in animals and humans in the same location that may be responsible for the introduction of new RV strains in future or of human rotavirus strains that could be pathogenic to the animal population. Outcome of such studies will have direct impact on public health and on the development of intervention strategies.
Acknowledgments. The authors are thankful to Dr. D. T. Mourya, Director, National Institute of Virology, Pune, India for all the support. Thanks are due to Dr. V.C. Ingle, Department of Veterinary Microbiology and Animal Biotechnology, Nagpur, India for extending their cooperation in sample collection.

\section{References}

Sugiyama M (2009): Molecular epidemiology of rotaviruses among healthy calves in Japan: isolation of a novel bovine rotavirus bearing new P and G genotypes. Virus Res. 144, 250-257. https://doi.org/10.1016/j.virusres.2009.05.005

Cashman O, Lennon G, Sleator RD, Power E, Fanning S, O'Shea $\mathrm{H}$ (2010): Changing profile of the bovine rotavirus G6 population in the south of Ireland from 2002 to 2009. Vet. Microbiol. 146, 238-244. https://doi.org/10.1016/j. vetmic.2010.05.012

Chakraborty P, Bhattacharjee MJ, Sharma I, Pandey P, Barman NN (2016): Unusual rotavirus genotypes in humans and animals with acute diarrhoea in Northeast India. Epidemiol. Infect. 144, 2780-2789. https://doi.org/10.1017/ $\underline{\mathrm{S} 0950268816000807}$

Chitambar SD, Arora R, Kolpe AB, Yadav MM, Raut CG (2011): Molecular characterization of unusual bovine group $\mathrm{A}$ rotavirus G8P[14] strains identified in western India: emergence of $\mathrm{P}[14]$ genotype. Vet. Microbiol. 148, 384-148. https://doi.org/10.1016/j.vetmic.2010.08.027

Chitambar SD, Tatte V, Dhongde R, Kalrao V (2008): High frequency of rotavirus viremia in children with acute gastroenteritis discordance of strains detected in stool and sera. J. Med. Virol. 80, 2169-2176. https://doi. org/10.1002/jmv. 21338

Collins PJ, Martella V, Buonavoglia C, O'Shea H (2010): Identification of a G2-like porcine rotavirus bearing a novel VP4 type, P[32]. Vet. Res. 41, 73. https://doi.org/10.1051/ vetres/2010045

Dhama K, Chauhan RS, Mahendran M, Malik SVS (2009): Rotavirus diarrhea in bovines and other domestic animals. Vet. Res. Comm. 33, 1-23. https://doi.org/10.1007/ s11259-008-9070-x

Dubal ZB Bhilegaonkar KN, Barbuddhe SB, Kolhe RP, Kaur S, Rawat S Nambiar P, Karunakaran M (2013): Prevalence and genotypic ( $\mathrm{G}$ and $\mathrm{P}$ ) determination of porcine group A rotaviruses from different regions of India. Trop. Anim. Health Prod. 45, 609-615. https://doi.org/10.1007/ $\underline{\text { s11250-012-0267-1 }}$

Estes MK, Kapikian AZ (2007): Rotaviruses. In Knipe DM, Howley PM (Ed.): Fields Virology. 5th ed., vol 2. Lippincott Williams \& Wilkins, Philadelphia, PA, pp. 1917-1973.

Gentsch JR, Laird AR, Bielfelt B, Griffin DD, Banyai K, Ramachandran M, Jain V, Cunliffe NA, Nakagomi O, Kirkwood CD, Fischer TK, Parashar UD, Bresee JS, Jiang B, Glass RI (2005): Serotype diversity and reassortment between human and animal rotavirus strains: implications for rotavirus vaccine programs. J. Infect. Dis. 192, S146-S159. https://doi.org/10.1086/431499 
Ghosh S, Navarro R, Malik YS, Willingham AL, Kobayashi N (2015): Whole genomic analysis of a porcine G6P[13] rotavirus strain. Vet. Microbiol. 180, 286-298. https:// doi.org/10.1016/j.vetmic.2015.09.017

Ghosh S, Varghese V, Samajdar S, Sinha M, Kobayashi N, Naik TN (2007): Molecular characterization of bovine group A rotavirus G3P[3] strains. Arch. Virol. 152, 1935-1940. https://doi.org/10.1007/s00705-007-1009-y

Iturriza-Gómara M, Anderton E, Kang G, Gallimore C, Phillips W, Desselberger U, Gray J (2003): Evidence for genetic linkage between the gene segments encoding NSP4 and VP6 proteins in common and reassortant human rotavirus strains. J. Clin. Microbiol. 41, 3566-3573. https://doi. org/10.1128/JCM.41.8.3566-3573.2003

Iturriza-Gómara M, Dallman T, Bányai K, Böttiger B, Buesa J, Diedrich S, Fiore L, Johansen K, Koopmans M, Korsun N, Koukou D, Kroneman A, László B, Lappalainen M, Maunula L, Marques AM, Matthijnssens J, Midgley S, Mladenova Z, Nawaz S, Poljsak-Prijatelj M M, Pothier P, Ruggeri FM, Sanchez-Fauquier A, Steyer, A, Sidaraviciute- Ivaskeviciene I, Syriopoulou V, Tran AN, Usonis V, Van Ranst M, De Rougemont A, Gray J (2011): Rotavirus genotypes co-circulating in Europe between 2006 and 2009 as determined by EuroRotaNet, a panEuropean collaborative strain surveillance network. Epidemiol. Infect. 139, 895-909. https://doi.org/10.1017/ $\underline{\text { S0950268810001810 }}$

Kumar N, Malik YS, Sharma K, Dhama K, Ghosh S, Bányai K, Kobayashi N, Singh RK (2018): Molecular characterization of unusual bovine rotavirus A strains having high genetic relatedness with human rotavirus: evidence for zoo anthroponotic transmission. Zoonoses Public Health. https:/doi.org/10.1111/zph.12452. [Epub ahead of print] https://doi.org/10.1111/zph.12452

Malik YS, Sharma K, Vaid N, Chakravarti S, Chandrashekar KM, Basera SS, Basera, SS, Singh R, Minakshi PG, Gulati BR, Bhilegaonkar KN, Pandey AB, (2012): Frequency of group A rotavirus with mixed $\mathrm{G}$ and $\mathrm{P}$ genotypes in bovines: predominance of G3 genotype and its emergence in combination with G8/G10 types. J. Vet. Sci.13, 271-278. https://doi.org/10.4142/jvs.2012.13.3.271

Maneekarn N, Khamrin P, Chan-it W, Peerakome S, Sukchai S, Pringprao K, Ushijima H (2006): Detection of rare $\mathrm{G} 3 \mathrm{P}[19]$ porcine rotavirus strains in Chiang Mai, Thailand, provides evidence for origin of the VP4 genes of Mc323 and Mc345 human rotaviruses. J. Clin. Microbiol. 44, 4113-4119. https://doi.org/10.1128/JCM.00954-06

Manuja BK, Prasad M, Manuja A, Gulati BR, Prasad G (2008): A novel genomic constellation (G10P[3]) of group A rotavirus detected from buffalo calves in northern India. Virus Res. 138, 36-42. https://doi.org/10.1016/j. virusres.2008.08.006

Martella V, Bányai K, Matthijnssens J, Buonavoglia C, Ciarlet M (2010): Zoonotic aspects of rotaviruses. Vet. Microbial. 140, 246-255. https://doi.org/10.1016/j.vet$\underline{\text { mic.2009.08.028 }}$

Martella V, Ciarlet M, Bányai K, Lorusso E, Arista S, Lavazza A, Pezzotti G, Decaro, N, Cavalli A, Lucente MS, Corrente
M, Elia G, Camero M, Tempesta M, Buonavoglia C (2007): Identification of group A porcine rotavirus strains bearing a novel VP4 (P) genotype in Italian swine herds. J. Clin. Virol. 45, 577-580.

Matthijnssens J, Ciarlet M, Rahman M, Attoui H, Bányai K, Estes MK, Gentsch JR, Iturriza Gómara M, Kirkwood CD, Martella V, Mertens PP, Nakagomi O, Patton JT, Ruggeri FM, Saif LJ, Santos N, Steyer A, Taniguchi K, Desselberger U, Van Ranst M (2008): Recommendations for the classification of group A rotaviruses using all 11 genomic RNA segments. Arch. Virol. 153, 1621-1629. https://doi. org/10.1007/s00705-008-0155-1

Matthijnssens J, Ciarlet, M, McDonald SM, Attoui H, Bányai K, Brister JR, Buesa, J., Esona M.D, Estes MK, Gentsch JR, Iturriza-Gómara M, Johne R, Kirkwood CD, Martella V, Mertens PP, Nakagomi O, Parre-o V, Rahman M, Ruggeri FM, Saif LJ, Santos N, Steyer A, Taniguchi K, Patton JT, Desselberger U, Van Ranst M (2011): Uniformity of rotavirus strain nomenclature proposed by the Rotavirus Classification Working Group (RCWG). Arch. Virol. 156, 1397-1413. https://doi.org/10.1007/s00705-011-1006-Z

Matthijnssens J, Rahman M, Ciarlet M, Zeller M, Heylen E, Nakagomi T, Uchida R, Hassan Z, Azim T, Nakagomi O, Van Ranst M (2010): Reassortment of human rotavirus gene segments into G11 rotavirus strains. Emerg. Infect. Dis. 16, 625-630. https://doi.org/10.3201/eid1604.091591

Midgley SE, Bányai K, Buesa J, Halaihel N, Hjulsager CK, Jakab F, Kaplon J, Larsen LE, Monini M, Poljšak-Prijatelj M, Pothier P, Ruggeri FM, Steyer A, Koopmans M, Böttiger B (2012): Diversity and zoonotic potential of rotaviruses in swine and cattle across Europe. Vet. Microbiol. 156, 238-245. https://doi.org/10.1016/j.vetmic.2011.10.027

Miyazaki A, Kuga K, Suzuki T, Tsunemitsu H (2012): Analysis of the excretion dynamics and genotypic characteristics of rotavirus A during the lives of pigs raised on farms for meat production. J. Clin. Microbiol. 50, 2009-2017 https://doi.org/10.1128/JCM.06815-11

Mondal A, Chakravarti S, Majee SB, Bannalikar AS (2013): Detection of picobirnavirus and rotavirus in diarrheic faecal samples of cattle and buffalo calves in Mumbai metropolis, Western India. Vet. Ital. 49, 357-360.

Nagai M, Shimada, S, Fujii Y, Moriyama H, Oba M, Katayama Y, Tsuchiaka S, Okazaki S, Omatsu T, Furuya T, Koyama S, Shirai J, Katayama K, Mizutani T (2015): H2 genotypes of G4P [6], G5P[7], and G9[23] porcine rotaviruses show super-short RNA electropherotypes. Vet. Microbiol. 176, 250-256. https://doi.org/10.1016/j.vetmic.2015.02.002

Papp H, László B, Jakab F, Ganesh B, De Grazia S, Matthijnssens J, Ciarlet M, Martella V, Bányai K (2013): Review of group A rotavirus strains reported in swine and cattle. Vet. Microbiol. 165, 190-199. https://doi.org/10.1016/j. vetmic.2013.03.020

Parra GI, Vidales G, Gomez JA, Fernandez FM, Parreño V, Bok K (2008): Phylogenetic analysis of porcine rotavirus in Argentina: increasing diversity of G4 strains and evidence of interspecies transmission. Vet. Microbiol. 126, 243-250. https://doi.org/10.1016/j.vetmic.2007.06.006 
Pourasgari F, Kaplon J, Karimi-Naghlani S, Fremy C, Otarod V, Ambert-Balay K, Mirjalili A, Pothier P (2016): The molecular epidemiology of bovine rotaviruses circulating in Iran: a two-year study. Arch. Virol. 161, 3483-3494. https://doi.org/10.1007/s00705-016-3051-0

Saikruang W, Khamrin P, Chaimongkol N, Suantai B, Kongkaew A, Kongkaew S, Ushijima H, Maneekarn N (2013): Genetic diversity and novel combinations of G4P[19] and G9P [19] porcine rotavirus strains in Thailand. Vet. Microbiol. 161, 255-262. https://doi.org/10.1016/j.vetmic.2012.07.036

Santos N, Hoshino Y (2005): Global distribution of rotavirus serotypes/ genotypes and its implication for the development and implementation of an effective rotavirus vaccine. Rev. Med. Virol. 15, 29-56. https://doi.org/10.1002/rmv.448

Sharma G, Taku A, Chhabra R, Bhat MA (2009) Prevalence of bovine rotaviral diarrhoea in Jammu. Ind. J. Virol. 20, 53-58.

Steyer A, Poljsak-Prijatelj M, Barlic-Maganja D, Marin J (2008): Human, porcine and bovine rotaviruses in Slovenia: evidence of interspecies transmission and genome reassortment. J. Gen. Virol. 89, 1690-1698. https://doi.org/10.1099/ vir.0.2008/001206-0

Tamura K, Peterson D, Peterson N, Stecher G, Nei M, Kumar S (2011): MEGA5: molecular evolutionary genetics analysis using maximum likelihood, evolutionary distance, and maximum parsimony methods. Mol. Biol. Evol. 28, 2731-2739. https://doi.org/10.1093/molbev/msr121

Tate JE, Burton AH, Boschi-Pinto C, Steele AD, Duque J, Parashar UD, WHO-coordinated Global Rotavirus Surveillance Network. 2012 (2012): 2008 estimate of worldwide rotavirus-associated mortality in children younger than 5 years before the introduction of universal rotavirus vaccination programmes: a systematic eview and metaanalysis. Lancet Infect. Dis. 12, 136-141. https://doi. org/10.1016/S1473-3099(11)70253-5

Theuns S, Heylen E, Zeller M, Roukaerts ID, Desmarets LM, Van Ranst M, Nauwynck HJ, Matthijnssens J (2015): Complete genome characterization of recent and ancient Belgian pig group A rotaviruses and assessment of their evolutionary relationship with human rotaviruses. J. Virol. 15, 1043-1057. https://doi.org/10.1128/JVI.02513-14

Theuns S, Vyt P, Desmarets LMB, Roukaerts IDM, Heylen E, Zeller M, Matthijnssens J, Nauwynck HJ (2016): Presence and characterization of pig group $\mathrm{A}$ and $\mathrm{C}$ rotaviruses in feces of Belgian diarrheic suckling piglets. Virus Res. 213, 172-183. https://doi.org/10.1016/j.virusres.2015.12.004

Thompson JD, Higgins DG, Gibson TJ (1994): CLUSTAL W: improving the sensitivity of progressive multiple sequence alignment through sequence weighting, position-specific gap penalties and weight matrix choice. Nucleic Acids Res. 22, 4673-4680. https://doi.org/10.1093/nar/22.22.4673

Varshney B, Jagannath MR, Vethanayagam RR, Kodhandharaman S, Jagannath HV, Gowda K, Singh DK, Rao CD (2002): Prevalence of, and antigenic variation in, serotype G10 rotaviruses and detection of serotype G3 strains in diarrheic calves: implications for the origin of G10P11 or P11 type reassortant asymptomatic strains in newborn children in India. Arch. Virol. 147, 143-165. https://doi. org/10.1007/s705-002-8308-Z 